\title{
Sero-Epidemiological Study of Hepatitis E Virus among Thalassemia as High Risk Patients: A Cross-Sectional Survey in Jahrom, Southern, Iran
}

\author{
Abdolreza Sotoodeh Jahromi ${ }^{1}$, Abbas Ahmadi-vasmehjani ${ }^{2}$, Hassan Zabetian ${ }^{2}$, Hossein Hakimelahi ${ }^{2}$, Alireza \\ Yusefi $^{2}$, Mohammad Sadegh Sanie ${ }^{2}$, Somayehsadat Talebnia Jahromi ${ }^{2}$, Masoud Ghanei ${ }^{2}$, Abdolali Sapidkar ${ }^{2}$, \\ Saiedeh Erfanian 2 , Abdolhossien Madani ${ }^{3}$, Farshid Kafilzadeh ${ }^{4}$, Mohammad Kargar ${ }^{4} \&$ Mohammad \\ Hojjat-Farsangi $^{5}$ \\ ${ }^{1}$ Zonoses Research Center, Jahrom University of Medical Sciences, Jahrom, Iran \\ ${ }^{2}$ Research Center for Social Determinants of Health, Jahrom University of Medical Sciences, Jahrom, Iran \\ ${ }^{3}$ Research Center for Social of Determinants on Health Promotion, Hormozgan University of Medical Sciences, \\ Bandarabbas, Iran \\ ${ }^{4}$ Department of biology, Jahrom branch, Islamic Azad University, Jahrom, Iran \\ ${ }_{5}^{5}$ Department of Oncology-Pathology, Immune and Gene Therapy Lab, Cancer Center Karolinska (CCK), \\ Karolinska University Hospital Solna and Karolinska Institute, Stockholm, Sweden
}

Correspondence: Hassan Zabetian, Research Center for Social Determinants of Health, Jahrom University of Medical Sciences, Jahrom, Iran. Tel: 98-71-54340405. E-mail: sotoodehj2002@yahoo.com

Received: October 8, 2015 Accepted: December 14, 2015 Online Published: January 31, 2016

doi:10.5539/gjhs.v8n9p245 URL: http://dx.doi.org/10.5539/gjhs.v8n9p245

\begin{abstract}
Hepatitis E virus (HEV) could be cause of viral hepatitis in the developing countries and cause severe epidemics. According to other studies, blood transfusion as a probable route of HEV infection has been suggested. An infection with hepatitis agents such as HEV causes active liver failure in multi-transfusion patients in particular thalassemia. The purpose of this study determines the seropositivity of anti-HEV antibodies in thalassemia individuals in Jahrom. In a cross-sectional study, sera from 110 thalassemia were collected between 2013 and 2014. Enzyme-linked immunosorbent assay (ELISA) method was performed to detection of anti-HEV antibodies. Individuals' data were collected such as, demographic and clinical, for statistical analysis. Our results show that $10 \%$ and $1.8 \%$ of the enrolled patients were HEV Ig-G and Ig-M positive antibodies respectively. In addition, there was statiscally significant difference in age groups for prevalence of anti-HEV Ig-G $(P=0.01)$. Also the serum levels of liver enzymes such as ALT and AST in the HEV Ig-G and Ig-M positive samples were significantly higher than anti-HEV negative samples. But there were no significant difference between sex and splenectomy with anti-HEV positive samples. The results indicate more study are needed to assess HEV screening of blood products to these patients that those have a probably risk of exposure to HEV especially in higher years old.
\end{abstract}

Keywords: Hepatitis E Virus (HEV), prevalence, thalassemia, Jahrom

\section{Introduction}

Hepatitis E virus (HEV) belongs to genus Hepevirus of the Hepeviridae family that a small nonenveloped single-stranded RNA virus (Cheng et al., 2012). Infection of hepatitis agents usually leads to benign acute hepatitis, but be fulminant particularly in patients with chronic liver disease (CLD) (Ahmadi Vasmehjani, Javeshghani, Baharlou, Shayestehpour, Mousavinasab, Joharinia, \& Enderami, 2015). Also this virus is the etiologic agent for liver injury in endemic regions of world (Acharya \& Panda, 2005). It is noted that HEV infection is a main health concern in developing countries such as Iran because it occur to large epidemic in endemic regions and also to sporadic forms in developed regions (Peron, Mansuy, Izopet, \& Vinel, 2006).

Transmission of HEV infection occurs by the fecal-oral route and dirty water that plays an important role in transmission route (Peron, Mansuy, Izopet, \& Vinel, 2006). Also in high endemic areas, vertical and transfusion of infected blood products, is able to cause this way associated hepatitis E, are other approaches for its 
transmission (Acharya \& Panda, 2005). Of course, risk of taking hepatitis E virus increase with age as seroprevalence of HEV infection varied with age, from 3.3\%-37.5\% (Taremi, Gachkar, Mahmoudarabi, Kheradpezhouh, \& Khoshbaten, 2007). Previous authors have indicated a relatively seroprevalence of antibody to HEV in their hemodialysis and thalassemia patients (Abdel, M. S., El-Din, \& M. E., El-Din, 1998; Halfon et al., 1994; Morteza, AbdolReza, \& Hamid, 2009; Sayani et al., 2014). According to this view, patients with hemophilia and thalassemia are at higher risk of transfusion-borne viruses such as hepatitis C (HCV), TTV and other viruses (Alavian et al., 2009; Ataei, Emami Naeini, Khorvash, Yazdani, \& Javadi, 2012; Sara, Solhjoo, Jahromi, \& Yaghobi, 2012). Therefore this high risk groups are prone to infection with other viral hepatitis especially HEV that could lead to active and severe hepatic failure as a results in these cases, elevated liver enzyme levels is reported (Gotanda et al., 2007; Jahromi \& Pourahmad, 2013).

Differences in epidemiological patterns, geographical locations, age group, disease severity and other properties associated with hepatitis E infection in different regions (Aggarwal \& Naik, 2009). In Iran, HEV infection is located in a high endemic country that is a neglected problem in our region because few outbreaks, is may be a high risk of hepatitis E occurrence (Alavian, 2007). The seroprevalence of HEV is varied in different regions of Iran (Ahmad, Roya, Manoochehr, \& Nooshin, 2011; Ehteram et al., 2013; Morteza et al., 2009). The rate of seroprevalence of HEV infection in high risk such as hemodialysis patients with significance elevated liver enzyme levels were 7\% (Morteza et al., 2009) but this rate in thalassemia patients was different in other studies (Al-Fawaz et al., 1996; Elizee et al., 2013; Psichogiou et al., 1996).

According to these data, but the study of HEV infection seroprevalence in high risk groups have been little performed in Iran to explain the epidemiological and clinical properties of HEV infection in these individuals. Thus, the purpose of the current study investigates HEV seroprevalence in thalassemia patients in Iran and to evaluate clinical features such as age, sex, splenectomy in patients with positive and negative HEV antibodies.

\section{Materials and Methods}

\subsection{Study Population}

A cross-sectional study was carried out Coliz unit of Motahhari hospital related to the Jahrom University of Medical Science, Iran, during July from 2013 to December 2014. A total of 110 thalassemic patients were recruited for this study. Primary screening, including human immunodeficiency virus (HIV), Human T-cell leukemia (HTLV), and hepatitis B and C were performed in all individuals and with any positive result were excluded. Information related to demographic characteristics such as sex, age and splenectomy were collected. Informed consent was obtained from all participants and their parents if the patients were under 18 years of age.

\subsection{Serological and Biochemical Laboratory Tests}

Serums of the patients were freeze at $-20^{\circ} \mathrm{C}$ to perform immunologic studies. Serum ALT and AST levels were measured using an analyzer and values higher than 50 and $40 \mathrm{IU} / \mathrm{L}$, respectively, Immunoglobulin G (IgG) and M (IgM) antibodies against HEV were detected using ELISA methods (DIA.PRO, Diagnostic Bioprobes Srl, Italy) according to the manufacturer instructions. The cut-off value was defined using positive and negative control sera that were included in each assay.

\subsection{Statistical Tests}

Data were entered and analyzed using SPSS software version 18.1. The Chi-square test or Fisher's exact test was used for categorical variables. Results were reported as percentages for qualitative variables. Chi-square test and $\mathrm{t}$-test were done and statistical significance was established at $\mathrm{P}$ values of $<0.05$.

\section{Results}

The individuals' information as demographical and clinical is shown in Table 1. Our finding shows that eleven patients ( $10 \%$ of the registered patients) were HEV Ig-G antibody positive and only two patients were HEV Ig-M antibody positive (Table 1). Table 2 shows the age groups, sex, splenectomy for patients with positive and negative HEV antibody, as well as their levels of ALT and AST. The highest rate of HEV positive samples came from individuals who were 11 to 20 years old. The seroprevalence of Ig-G also increased with age, rising from $0 \%$ in patients below 10 years to $10 \%$ in above 10 years group. In addition, there was significant difference in age groups for prevalence of Ig-G $(\mathrm{P}=0.01)$ (Table 2). The serum levels of ALT and AST in the HEV Ig-G and Ig-M positive samples were significantly higher than those in the anti-HEV negative samples. But there were no significant difference between sex and splenectomy with HEV Ig-G and Ig-M positive samples (Table 2). 
Table 1. Demographic and clinical data for the 110 thalassemia patients

\begin{tabular}{llll}
\hline Variables & N & $\mathbf{\%}$ & Mean \pm SD \\
\hline Age groups & 24 & 22.7 & $15.2 \pm 6$ \\
$\leq 10$ & 69 & 70.9 & \\
$11-20$ & 17 & 6.4 & \\
$>20$ & & & \\
Gender & 51 & 46.4 & \\
Male & 59 & 53.6 & \\
Female & & & \\
\hline Splenectomy & 49 & 44.5 & $19.3 \pm 12.9$ \\
Yes & 61 & 55.5 & \\
No & & & \\
ALT (IU/L) & & & \\
AST (IU/L) & & 10 & \\
HEV Ig-G & 11 & 90 & \\
Positive & 99 & 1.8 & \\
Negative & & 98.2 & \\
HEV Ig-M & & & \\
Positive & 2 & & \\
Negative & 108 & & \\
\hline
\end{tabular}

Table 2. Prevalence of anti-HEV IgG and Ig-M antibodies in 90 HIV patients in relation to demographic and clinical data

\begin{tabular}{lllllll}
\hline Characteristics & $\begin{array}{l}\text { HEV Ig-G } \\
\text { positive }\end{array}$ & $\begin{array}{l}\text { HEV Ig-G } \\
\text { negative }\end{array}$ & $\begin{array}{l}\text { P-value } \\
\text { N (\%) }\end{array}$ & $\begin{array}{l}\text { HEV Ig-M positive } \\
\text { N (\%) }\end{array}$ & $\begin{array}{l}\text { HEV Ig-M negative } \\
\text { N (\%) }\end{array}$ & P-value \\
\hline Gender & & & & & \\
Male & $3(5.9 \%)$ & $48(94.1 \%)$ & 0.15 & $1(2 \%)$ & $50(98 \%)$ & 0.71 \\
Female & $8(3.6 \%)$ & $51(86.4 \%)$ & & $1(1.7 \%)$ & $58(98.3 \%)$ & \\
Age groups & & & & & \\
$\leq 10$ & $0(0 \%)$ & $24(100 \%)$ & 0.01 & $0(0 \%)$ & $24(100 \%)$ & 0.18 \\
$11-20$ & $7(10.2 \%)$ & $62(89.8 \%)$ & & $1(1.5 \%)$ & $68(98.5 \%)$ & \\
$>20$ & $4(23.5 \%)$ & $13(76.5 \%)$ & & $1(5.9 \%)$ & $16(94.1 \%)$ & \\
Splenectomy & & & & & & \\
Yes & $5(10.2 \%)$ & $44(89.8 \%)$ & 0.59 & $1(2.9 \%)$ & $48(97.1 \%)$ & 0.69 \\
No & $6(9.8 \%)$ & $55(90.2 \%)$ & & $1(1.6 \%)$ & $60(98.4 \%)$ & 0.001 \\
ALT (IU/L) & $43.3 \pm 32.7$ & $19 \pm 19.7$ & 0.001 & $134 \pm 11.3$ & $19.4 \pm 16.4$ & 0.001 \\
AST (IU/L) & $25.7 \pm 21.8$ & $18.6 \pm 11.5$ & 0.05 & $69.5 \pm 21.9$ & $18.4 \pm 10.9$ & \\
\hline
\end{tabular}

\section{Discussion}

The transfusion of frequent blood products could be alternative route for cause different disease by infectious agent such as hepatitis C and hepatitis B. Also this condition in these individuals could be leads to physiological problems such as liver injury. Of course this programmed injection in these patients such as hemophilia and 
thallesemia is critical because the risk of viral hepatitis arising from their needs to blood products. On other hand, there is higher risk of transmission through transfusion for these patients in developing regions than other locations, therefore is very threatening. Based on these possibilities, there are different reports based on parenteral HEV exposure with transmission through transfusion in endemic and nonendemic areas. Therefore the prevalence of HEV antibodies in high risk patients in each region for preventing of high therapy costs is critical.

In our study, the rate of HEV Ig-M and Ig-G antibodies in thallesemia patients were $1.8 \%$ and $10 \%$. Previous reports have demonstrated a variety of seroprevalence rates of HEV infection in high risk patients in different regions of Iran (Elizee et al., 2013; Morteza et al., 2009; Taremi, Khoshbaten, Gachkar, Ehsani Ardakani, \& Zali, 2005). The seroprevalence of antibody against HEV in thallesemia patients of other parts of world were $0.4 \%$, 2.4\%, 10.7\% (Al-Fawaz et al., 1996; Hossein Keyvani, n.d.; Psichogiou et al., 1996). One of the studies followed active HEV infection by detection of Ig-M antibody that no individuals was found positive for Ig-M but in our report two of the patients have active HEV infection. In several studies the rate of seroprevalence of Ig-G antibody in other individuals such as blood receipts and donors in different parts of world were performed (Ahmad et al., 2011; Gao et al., 2004; Matsubayashi et al., 2011; Ma et al., 2015). Also the total seroprevalence of IgG antibody in Iranian blood donors in different regions were 4.5\% in Tehran 2009 ("Seroprevalence of anti-HEV and HEV RNA among volunteer blood donors and patients with Hepatitis B and C in Iran,"), 5.5\% and $8.5 \%$ in Jahrom ("Hepatitis E virus and serum level aminotransferases in blood donors,"; "Seroprevalence Of Hepatitis Virus In Blood Donors"), a town of the southern of Iran, 14.3\%, urban and rural areas of central province of Iran (Ehteram et al., 2013). Therefore, our data shown that the rate of Ig-M and Ig-G antibodies in Jahrom, southern of Iran, was higher or lower than other parts of Iran and world of course this rate was similar to other reports. There were different approaches in the cases of various seroprevalence in over world. Noting reasons such as demographical and geographical differences in according to academic and developing regions could be varied incidence of HEV infection (Aggarwal \& Naik, 2009). In addition to major transmission route of HEV infection, oral-fecal, this seems to be a probably reason that repeated transfusion effects on getting HEV infection therefore these individuals may be prone to HEV infection. Another possibility is that individuals with anti-HEV Ig-G might have been transferred passively by transfusions and defect expression of acquired immunity. On other hand, the importance of HEV infection in relation to blood multi-transfusion suggesting increased the possibility that the virus could be parenterally exposure or a possibility of combined route of transmission.

Because the HEV infection is hepatotropic, therefore HEV could be the leading cause of acute viral hepatitis (Bhatia, Singhal, Panda, \& Acharya, 2008). In our study, liver enzymes levels such as ALT and AST in patients with positive anti-HEV was higher than anti-HEV negative patients. However our and previous studies shown that elevated ALT may be due to sub-clinical HEV infections (Gao, Peng, Zhu, Sun, Zheng, \& Zhang, 2004). Therefore in patients with Unexplainable elevated ALT and AST, hepatitis E as an alternative diagnosis is reasonable. In recent study, thalassemia patients may represent the convalescent phase of a previous exposure and potentially able to cause transfusion associated hepatitis E. The presence of patients with double positive antibodies (Ig-M and Ig-G), who ALT levels were higher than HEV single negative subjects indicated that HEV-associated hepatitis due to transfusion transmission may be occur but cannot be deduced from the higher levels of double antibodies and high ALT levels.

In the current study, a significantly trend of seropositivity associated with increasing age between 11-20 years was observed but decreased in over 20 years old. The seroprevalence in other studies among individuals in HEV endemic and no endemic regions was significantly increased with age. They reported that HEV seroprevalence increased with age from $0.9 \%$ in children aged 6-9 years to $8.1 \%$ in people over 50 years old (Ataei et al., 2009). This condition may be due to an epidemic form of HEV infection which happened in some decades ago, when the sanitary conditions in our country were poor. Generally, potential transfusion of HEV-specific antibodies to the individuals of multiple blood such as thalassemia patients and rising seroprevalence to HEV in over years old and also significantly decreased risk of after-transfusion HEV infection.

In conclusion, this study shows a relatively prevalence of anti-HEV in high risk groups, especially thalassemia patients. Also we thought that an asymptomatic infection of HEV may have lead to the elevated ALT and AST levels in our patients and may have been due to HEV-associated hepatitis. Therefore more studies using polymerase chain reaction techniques are required to confirm whether HEV infection through blood or transfusion is possible. Furthermore, more study are needed to assess HEV screening of blood products to these patients that those have a probably risk of exposure to HEV especially in higher years old. 


\section{Conflict of Interest}

The authors declare that there is no conflict of interests regarding the publication of this paper.

\section{References}

Ahmadi Vasmehjani, A., Javeshghani, D., Baharlou, R., Shayestehpour, M., Mousavinasab, S. D., Joharinia, N., \& Enderami, E. (2015). Hepatitis A infection in patients with chronic viral liver disease: A cross-sectional study in Jahrom. Iran Epidemiol. Infect, 143, 534-539. http://dx.doi.org/10.1017/S0950268814000806

Abdel, H. S., El-Din, M. S., \& El-Din, M. E. (1997). A high hepatitis E virus (HEV) seroprevalence among unpaid blood donors and haemodialysis patients in Egypt. The Journal of the Egyptian Public Health Association, 73(3-4), 165-179.

Acharya, S. K., \& Panda, S. K. (2005). Hepatitis E virus: epidemiology, diagnosis, pathology and prevention. Tropical gastroenterology: official journal of the Digestive Diseases Foundation, 27(2), 63-68.

Aggarwal, R., \& Naik, S. (2009). Epidemiology of hepatitis E: Current Status. Journal of gastroenterology and hepatology, 24(9), 1484-1493. http://dx.doi.org/10.1111/j.1440-1746.2009.05933.x

Ahmad, S., Roya, N., Manoochehr, M., \& Nooshin, S. (2011). Seroprevalence of Hepatitis E Virus Infection in Children in the Southwest of Iran. Hepatitis Monthly, 2009(4, Autumn), 261-264.

Alavian, S. M. (2007). Hepatitis E Virus Infection: A Neglected Problem in Our Region. Hepatitis Monthly, 7(3), 119-121.

Alavian, S. M., Miri, S. M., Keshvari, M., Elizee, P. K., Behnava, B., Tabatabaei, S. V., \& Lankarani, K. B. (2009). Distribution of hepatitis $C$ virus genotype in Iranian multiply transfused patients with thalassemia. Transfusion, 49(10), 2195-2199. http://dx.doi.org/10.1111/j.1537-2995.2009.02252.x

Al-Fawaz, I., Al-Rasheed, S., Al-Mugeiren, M., Al-Salloum, A., Al-Sohaibani, M., \& Ramia, S. (1996). Hepatitis $\mathrm{E}$ virus infection in patients from Saudi Arabia with sickle cell anaemia and $\beta$-thalassemia major: possible transmission by blood transfusion. Journal of viral hepatitis, 3(4), 203-205. http://dx.doi.org/10.1111/j.1365-2893.1996.tb00096.x

Ataei, B., Nokhodian, Z., Javadi, A. A., Kassaian, N., Shoaei, P., Farajzadegan, Z., \& Adibi, P. (2009). Hepatitis E virus in Isfahan Province: a population-based study. International Journal of Infectious Diseases, 13(1), 67-71. http://dx.doi.org/10.1016/j.ijid.2008.03.030

Ataei, B., Emami Naeini, A., Khorvash, F., Yazdani, M. R., \& Javadi, A.-A. (2012). Prevalence of transfusion transmitted virus infection in hemodialysis patients and injection drug users compared to healthy blood donors in Isfahan, Iran. Gastroenterology research and practice, 2012. http://dx.doi.org/10.1155/2012/671927

Bhatia V, S. A., Panda, S. K., \& Acharya, S. K. (2008). A 20-year single-center experience with acute liver failure during pregnancy: is the prognosis really worse? Hepatology, 48, 1577-1585. http://dx.doi.org/10.1002/hep.22493

Cheng, X.-F., Wen, Y.-F., Zhu, M., Zhan, S.-W., Zheng, J.-X., Dong, C., . . Han, L.-F. (2012). Serological and molecular study of hepatitis E virus among illegal blood donors. World journal of gastroenterology: WJG, 18(9), 986. http://dx.doi.org/10.3748/wjg.v18.i9.986

Ehteram, H., Ramezani, A., Eslamifar, A., Sofian, M., Banifazl, M., Ghassemi, S., . . Mashayekhi, P. (2013). Seroprevalence of Hepatitis E Virus infection among volunteer blood donors in central province of Iran in 2012. Iranian journal of microbiology, 5(2), 172.

Elizee, P. K., Alavian, S. M., Miri, S. M., Behnava, B., Alavian, S. H., Keshvari, M., . . Shafiei, M. (2013). The seroprevalence of entrically transmitted viral hepatitis in hcv infected thalassemia and hemophilia patients in iran. Jundishapur Journal of Microbiology, 6(7).

Gao, D., Peng, G., Zhu, J., Sun, L., Zheng, Y., \& Zhang, J. (2004). [Investigation of sub-clinical infection of hepatitis E virus in blood donors]. Chinese journal of hepatology, 12(1), 11-12.

Gotanda, Y., Iwata, A., Ohnuma, H., Yoshikawa, A., Mizoguchi, H., Endo, K., . . Okamoto, H. (2007). Ongoing subclinical infection of hepatitis E virus among blood donors with an elevated alanine aminotransferase level in Japan. Journal of medical virology, 79(6), 734-742. http://dx.doi.org/10.1002/jmv.20834

Halfon, P., Ouzan, D., Chanas, M., Khiri, H., Feryn, J., Mangin, L., . . Salvadori, J. (1994). High prevalence of hepatitis E virus antibody in haemodialysis patients. The Lancet, 344(8924), 746. 
http://dx.doi.org/10.1016/S0140-6736(94)92232-2

Hossein Keyvani, M. S. S., Saeed, N., Bashir, H., Farahnaz, F., \& Seyed-Moayed, A. (n.d.). Blood transfusion is not a risk factor for acquiring Hepatitis E virus infection among thalassemia and hemophilia patients. Viral Hepatitis Foundation Bangladesh, 33-37.

Jahromi, A. S., \& Pourahmad, M. (2013). Hepatitis e virus and serum level aminotransferases in blood donors. Rbmb Net, 2.

Matsubayashi, K. H. S. H. I., Sakata, H., \& Ikeda, H. (2011). Hepatitis E virus infection and blood transfusion in Japan. ISBT Science Series, 6(2), 344-349. http://dx.doi.org/10.1111/j.1751-2824.2011.01512.x

Ma, L., Sun, P., Lin, F., Wang, H., Rong, X., Dai, Y., . . . Su, N. (2015). Prevalence of hepatitis E virus in Chinese blood donors. Journal of International Medical Research, 0300060514562054. http://dx.doi.org/10.1177/0300060514562054

Morteza, P., AbdolReza, S., \& Hamid, N. (2009). Hepatitis E virus infection in hemodialysis patients: a seroepidemiological survey in Jahrom, Southern Iran. Hepatitis Monthly, 3(Summer), 232-235.

Peron, J. M., Mansuy, J. M., Izopet, J., \& Vinel, J. P. (2005). [Hepatitis E virus: an emerging disease]. Sante (Montrouge, France), 16(4), 239-243.

Psichogiou, M., Tzala, E., Boletis, J., Zakopoulou, N., Loutradi, A., Maliori, M., . . Hatzakis, A. (1996). Hepatitis $\mathrm{E}$ virus infection in individuals at high risk of transmission of non-A, non-B hepatitis and sexually transmitted diseases. Scandinavian journal of infectious diseases, 28(5), 443-445. http://dx.doi.org/10.3109/00365549609037936

Sara, A., Solhjoo, K., Jahromi, A. R. S., \& Yaghobi, R. (2012). Study the prevalence of TT virus infection in South Iranian volunteer blood donors. African Journal of Microbiology Research, 6(32), 6230-6234. http://dx.doi.org/10.5897/AJMR12.119

Sayani, F., Goldberg, D., Slaven, L., \& Russell, J. E. (2014). Hepatitis e infection in a patient with transfusion-dependent $\beta$ thalassemia. American Journal of Hematology, 90(3), E50-E50. http://dx.doi.org/10.1002/ajh.23905

Taremi, M., Khoshbaten, M., Gachkar, L., EhsaniArdakani, M., \& Zali, M. (2005). Hepatitis E virus infection in hemodialysis patients: a seroepidemiological survey in Iran. BMC infectious diseases, 5(1), 36. http://dx.doi.org/10.1186/1471-2334-5-36

Taremi, M., Gachkar, L., Mahmoudarabi, S., Kheradpezhouh, M., \& Khoshbaten, M. (2007). Prevalence of antibodies to hepatitis e virus among male blood donors in tabriz, Islamic Republic of Iran. East Mediterr Health J, 13(1), 98-102.

\section{Copyrights}

Copyright for this article is retained by the author(s), with first publication rights granted to the journal.

This is an open-access article distributed under the terms and conditions of the Creative Commons Attribution license (http://creativecommons.org/licenses/by/3.0/). 